\title{
IL5 wt Allele
}

National Cancer Institute

\section{Source}

National Cancer Institute. IL5 wt Allele. NCI Thesaurus. Code C50939.

Human IL5 wild-type allele is located in the vicinity of $5 q 31.1$ and is approximately $2 \mathrm{~kb}$ in length. This allele, which encodes interleukin-5 protein, is involved in eosinopoiesis or eosinophil maturation and activation. 